\title{
JUND Gene
}

National Cancer Institute

\section{Source}

National Cancer Institute. JUND Gene. NCI Thesaurus. Code C18428.

This gene plays a role in transcriptional regulation, apoptotic responses to cellular stress and signal transduction pathways. 